\author{
${ }^{1}$ H.A. Nasr, ${ }^{2,3}$ O.M. Nassar, ${ }^{1,4 *}$ M.H. El-Sayed, ${ }^{5}$ A.A. Kobisi \\ ${ }^{1}$ Department of Biology, Northern Border University, Kingdom of Saudi Arabia \\ ${ }^{2}$ Department of Home Economics, Northern Border University, Kingdom of Saudi Arabia \\ ${ }^{3}$ Nutrition and Food Sciences Department, Minufiya University, Minufiya, Egypt \\ ${ }^{4}$ Department of Botany and Microbiology, Faculty of Science, Al-Azhar University, Cairo, Egypt \\ ${ }^{5}$ Plant Protection Department, Desert Research Center, El-Mataria, Cairo, Egypt \\ *e-mail: m_helal2007rm@yahoo.com
}

\title{
Characterization and antimicrobial activity of lemon peel mediated green synthesis of silver nanoparticles
}

\begin{abstract}
For a long time, nanoparticle biosynthetic discipline is still under development and is known to have a big impact on numerous manufactures. Synthesis of nanoparticles by green methods with antimicrobial properties is of great researchers concern in the explored of new pharmaceutical and biomedical products. In this study, synthesis of silver nanoparticles (AgNPs) have been carried out using aqueous extract of lemon peel (Citrus limon), which acts as encapsulating cage for the silver nanoparticles. Synthesized AgNPs was monitored by formation of brown color, confirmed by UV/VIS spectra, which showed appearance of a surface plasmon resonance (SPR) band. FT-IR analysis of the bioextract after the addition of silver solution showed strong bands at 1021, 1443, 1634 and $3428 \mathrm{~cm}^{-1}$. Transmission electron microscopy examination of the solution containing AgNPs demonstrated spherical particles within nanoranged from $9.3 \mathrm{~nm}$ to $20.3 \mathrm{~nm}$ with the main diameter of $15.76 \mathrm{~nm}$. The biologically synthesized AgNPs showed a promising antimicrobial activity, where the maximal growth inhibition was recorded for both Pseudomonas (P.) aeruginosa and Escherichia (E.) coli-21.5 \pm 1.3 and $19.0 \pm 0.20 \mathrm{~mm}$, respectively. While the minimum growth inhibition was recorded for Gram positive bacteria Bacillus subtilis (B.) and Staphylococcus $(S$.) aureus $-15.0 \pm 0.20$ and $16.5 \pm 1.50 \mathrm{~mm}$, respectively. At the same time weak antifungal activity was observed for both Aspergillus (A.) flavus and Candida (C.) albicans $-14.0 \pm 0.15$ and $12.5 \pm 0.45 \mathrm{~mm}$, respectively.
\end{abstract}

Key words: green synthesis, silver nanoparticles, lemon peel extract, antimicrobial activity.

\section{Introduction}

In the fast development of nanomaterials in the quest for green, eco-friendly routes for new products often culminates in the utilization of microorganisms [1] and plant biomasses for the manufacture of sustainable nanocomposites $[2 ; 3]$ and nanoparticles [4-6], which are frequently used in biological approaches [7]. Nanotechnology mainly deals with the fabrication of nanoparticles having various shapes, sizes and managing their chemical and physical parameters for further use in human benefits with their growing applications in various fields [8]. Preparation of metal nano-sized, usually ranging in size from 1 to $100 \mathrm{~nm}$, is amongst the most emerging areas in the field of nanotechnology. Currently, the application of nano materials is becoming increasingly important in order to solve the problems associated with material sciences, including solar energy conversion, photonics $[9 ; 10]$, catalysis [11], microelectronics [12], antimicrobial functionalities [13], and water treatment [14]. Many biological routes of AgNPs synthesis have been reported using plant extracts, such as Citrus aurantium, Citrus limon, Capsicum annuum, Brassica oleracea, Aloe vera, Nigella sativa, Pulicaria glutinosa, Justicia glauca, Mimusops elengi L., and Coffea L. [15-26].

However, in most cases, a deep characterization of the biomolecule coating is not made. It is known that the reducing agents may include flavonoids, membrane proteins, NAD $(\mathrm{P})^{+}$reductases, dehydrogenases, citric acid, polyphenols, and secondary metabolites [27], whereas the capping agents may be extracellular proteins, enzymes, peptides, and tannic acids [28]. The AgNPs have various and important applications. Historically, silver has been known having a disinfecting effect and has been found in applications ranging from traditional medicines to culinary items. It has been reported 
that AgNPs are non-toxic to human and most effective against bacteria, virus and other eukaryotic micro-organism at low concentrations and without any side effects $[29 ; 30]$. Moreover, several salts of silver and their derivatives are commercially manufactured as antimicrobial agents [31]. A small concentration of silver is safe for human cells, but lethal for microorganisms [32]. Antimicrobial capability of AgNPs allows them to be suitably employed in numerous household applications such as textiles disinfection in water treatment, food storage containers, home appliances and in medical devices [33]. The most important application of silver and AgNPs is in medical industry such as tropical ointments to prevent infection against burn and open wounds [34]. Nowadays, biosynthesis of silver nanoparticles (AgNPs) had gained so much attention in developed countries due to development demand of environmental friendly technology for material synthesis. Thus, this study aims to show sustainable alternatives of new antimicrobial products based on nanomaterials by utilizing lemon waste to produce AgNPs that are active toward a number of pathogenic microorganisms.

\section{Materials and methods}

Chemicals. Chemicals and reagents used in the following experiments were of analytical grade. Silver nitrate $\left(\mathrm{AgNO}_{3}\right)$ salt was purchased from Techno Pharmchem, India. All the media components were from Oxoide, India.

Microbial strains. Antimicrobial activity was assayed against a panel of microorganisms certified by American Type Culture Collection (ATCC) and National Collection of Pathogenic Fungi (NCPF), including three Gram-positive bacteria Bacillus subtilis ATCC 6633 and Staphylococcus aureus ATCC 6538, and against Gram-negative Pseudomonas aeruginosa ATCC 9027 and Escherichia coli ATCC 7839, a fungus (yeast) - Candida albicans (NCPF-stock laboratory strain) filamentous fungi - Aspergillus flavus. Cultures were inoculated into specific broths and incubated at $37^{\circ} \mathrm{C}$ for $24 \mathrm{~h}$.

Collection of lemon peel. The lemon Citrus limon was purchased from two popular markets at Rafha governorate, Northern Border region in the Kingdom of Saudi Arabia. The collected lemon was washed, air-drying and subjected for peel obtaining in the laboratory under aseptic conditions.

Preparation of lemon peel biological extract. The collected lemon peel was washed and boiled in distilled water for $10 \mathrm{~min}$ at $90^{\circ} \mathrm{C} .100 \mathrm{~g}$ of the lemon peel were crushed in $200 \mathrm{~mL}$ of distilled water; resulting extract was filtered through a clean cloth and treated with equal volumes of chilled ethanol. Resulting precipitate was lyophilized into a powder for further experiments.

The green synthesis of silver nanoparticles (Ag$N P s)$. AgNPs were synthesized by bioreduction of $\mathrm{Ag}^{+} .5 \mathrm{~mL}$ of the fresh suspension of lemon peel extract (greenish in color) were added to $45 \mathrm{mlL} 0.002$ $\mathrm{M} \mathrm{AgNO}_{3}$ solution in $100 \mathrm{~mL}$ conical flasks at the room temperature in darkness for some period. The emulsion color turned to dark brown after adding of 1 $\mathrm{mM} \mathrm{AgNO}$ and stirring at room temperature.

Characterization of silver nanoparticles (AgNPS) as follows

UV/VIS spectral analysis. The synthesized silver nanoparticles were characterized spectrophotometrically using ultraviolet UV/VIS spectroscopy analyses as function of time at room temperature using Perkin Elmer UV/VIS spectrometer. Samples of aliquots $(0.2 \mathrm{ml})$ of the suspension were diluted with 2 $\mathrm{ml}$ deionized water and subsequently measured UV/ VIS spectra of the resulting diluents.

Fourier transform infrared spectrometer (FT$I R)$. FT-IR measurements were carried out in order to obtain information about chemical groups present around AgNPs for their stabilization and conclude the transformation of functional group due to reduction process. The measurements were carried out using JASCO FT-IR-3600 infra-red spectrometer by employing $\mathrm{KBr}$ Pellet technique.

Transmission electron microscopy (TEM). The size and morphology of the synthesized nanoparticles were recorded by using TEM model JEOL electron microscopy JEM-100 CX. TEM studies were prepared by drop coating silver nanoparticles onto carbon-coated TEM grids. The Film on the TEM grids were allowed to dry, the extra solution was removed using a blotting paper.

Assay of antimicrobial activity of the synthesized $A g N P s$. Antimicrobial activity was determined by the disk diffusion method [35], using cell suspensions with concentrations equilibrated to a $0.5 \mathrm{McF}$ arland standard for bacterial and unicellular fungal strains and loopful for the filamentous fungi. After incubation at appropriate incubation conditions, the plates were investigated and the diameters of inhibition zones were recorded.

Statistical analysis. All experiments were performed in triplicate and the values were expressed as mean \pm SD using Microsoft Excel 2016. 


\section{Results and discussion}

Buzzing of nanotechnology in each and every aspect of science and technology has been booming at a tremendous rate now a day. Nanotechnology has different applications in the field of physical, chemical and medical sciences; it has now started revolutionizing the drug delivery sciences [36].

Biological synthesis of nanoparticles by plant extracts is at present under exploitation as some researchers worked on it $[37 ; 38]$ and testing for antimicrobial activities [39-41]. For the last two decades, extensive work has been done to develop new drugs from natural products because of the resistance of microorganisms to the existing drugs. Nature has been an important source of a products currently used in medicinal practice [42].

Biosynthesis of silver nanoparticles by lemon peels bioextract. In the present study, synthesis of AgNPs by the lemon peel bioextract was carried out. Silver nitrate used has distinctive properties such as good conductivity, catalytic and chemical stability. The formation of AgNPs was found to be successful as suggested by initial changes in color. It is well known that AgNPs exhibit brown color (Figure 1a, b) in aqueous solution due to excitation of surface plasmon vibrations in AgNPs. It is well known that silver nanoparticles exhibit yellowish-brown color in aqueous solution due to excitation of surface plasmon vibrations in silver nanoparticles [43-45]. Reduction of the silver ion to silver nanoparticles during exposure to the peel extracts was followed by color change and as well as by UV/VIS spectroscopy.

Characterization of the synthesized silver nanoparticles AgNPs. Reduction of the silver ion to silver nanoparticles during exposure to the peel extract was followed by color change and as well as by UV/VIS spectroscopy. It is generally recognized that UV/VIS spectroscopy could be used to examine size and shape-controlled nanoparticles in aqueous suspensions. UV/VIS spectra that were recorded at different intervals for monitoring the reaction, the appearance of a surface plasmon resonance (SPR) band increased in intensity with time. It also reveals the production of silver nanoparticles within $1 \mathrm{~h}$. The UV/VIS absorption spectra recorded from the silver nanoparticles solution after $1.5 \mathrm{~h}$ of reaction (Figure 2). Metallic silver nanocrystals generally show a typical optical absorption peak at approximately $3 \mathrm{keV}$ due to the surface plasmon resonance [46-48]. This result confirmed that the produced nano-structures are pure silver. Therefore, metallic nanoparticles have spectrum in the UV/VIS region [49].

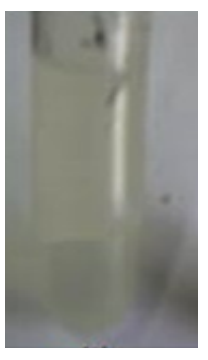

a

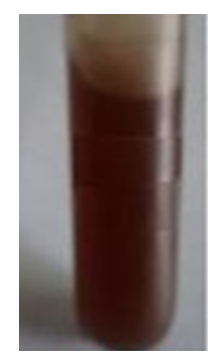

b
Figure 1 - Differential colouring dependent of AgNPs synthesis.

Note: a - extract of lemon peel (colorless), b - synthesized AgNPs (brown color)

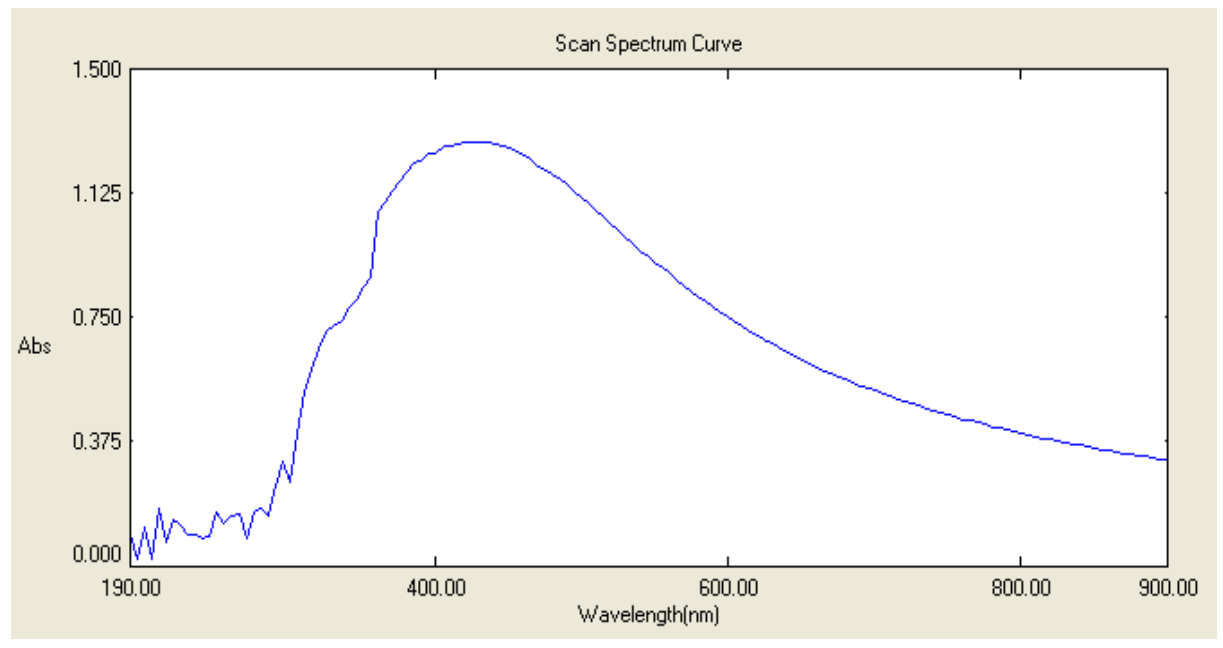

Figure 2 - UV/VIS spectra of reduced Ag ions to AgNPs with lemon peel bioextract 
Analysis of FT-IR absorption spectra of the bioextract after the addition of silver solution revealed the strong bands at 1021, 1443, 1634 and $3428 \mathrm{~cm}^{-1}$. The band at $1021 \mathrm{~cm}^{-1}$ corresponded to C-N stretching vibrations of amine. The band at $1443 \mathrm{~cm}^{-1}$ cor- responded to $\mathrm{C}-\mathrm{H}$ and $\mathrm{OH}$ bending and $3428 \mathrm{~cm}^{-1}$ was attributed to characteristic of $-\mathrm{NH}$ stretching of amide (II) band. The weaker band at $1634 \mathrm{~cm}^{-1}$ corresponded to amide I, arisen due to carbonyl stretch in proteins (Figure 3).

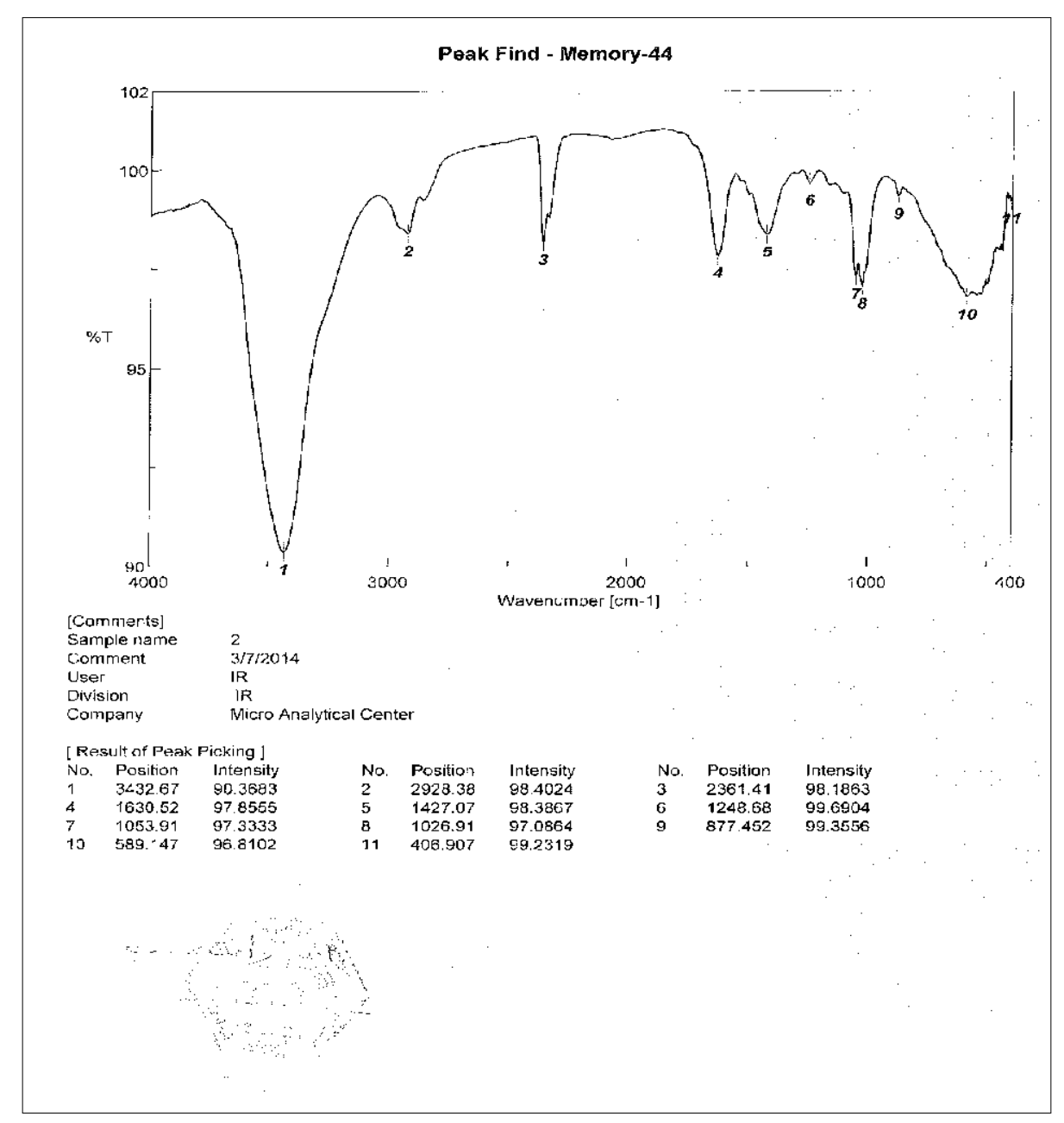

Figure 3 - FT-IR spectra of silver nanoparticles from lemon peel bioextract

FT-IR analysis of the synthesized AgNPs after the addition of silver solution revealed the strong bands at 1021, 1443, 1634 and 3428 $\mathrm{cm}^{-1}$. The positions of these bands were close to that reported formative proteins. The FT-IR results indicate that the secondary structure of proteins was not affected as a consequence of reaction with $\mathrm{Ag}^{+}$ions or binding with $\mathrm{AgNPs}$ [49].

Transmission electron microscopy (TEM) examination of the solution containing AgNPs demonstrated spherical particles within nanoranged from
$7.4 \mathrm{~nm}$ to $18.5 \mathrm{~nm}$ with the main diameter of 11.60 nm (Figure 4).

TEM examination of the solution containing AgNPs demonstrated spherical particles within nanoranged from $7.4 \mathrm{~nm}$ to $18.5 \mathrm{~nm}$ with the main diameter of $11.60 \mathrm{~nm}$. Similar AgNPs sizes synthesized from different sources were obtained various studies [49-51].

Antimicrobial activity of synthesized silver nanoparticles (AgNPs). The biologically synthesized AgNPs showed strong antimicrobial activity against number of the tested microbial strains (Table 1). 


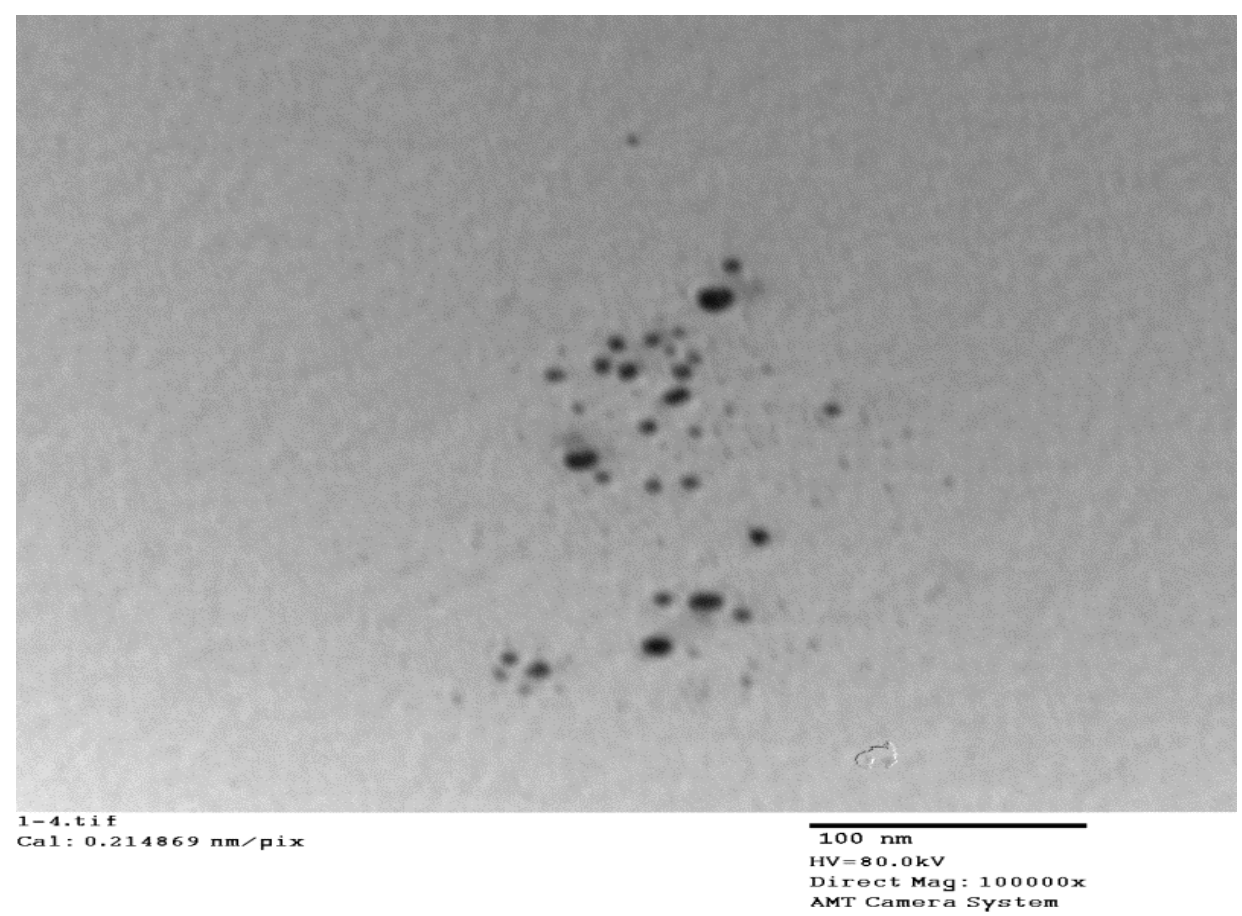

Figure 4 - TEM of the synthesized silver nanoparticles from lemon peel bioextract

Table 1 - Antimicrobial activity of silver nanoparticles from lemon peel

\begin{tabular}{|c|c|c|c|c|c|c|}
\hline \multirow{3}{*}{ Agent } & \multicolumn{6}{|c|}{ Mean diameter of inhibition zone (mm) } \\
\cline { 2 - 7 } & \multicolumn{2}{|c|}{ Gram positive bacteria } & \multicolumn{2}{|c|}{ Gram negative bacteria } & Unicellular fungi & Filamentous fungi \\
\cline { 2 - 7 } & $\begin{array}{c}\text { B. subtilis } \\
\text { ATCC 6633 }\end{array}$ & $\begin{array}{c}\text { S. aureus } \\
\text { ATCC 6538 }\end{array}$ & $\begin{array}{c}\text { P. aeruginosa } \\
\text { ATCC 9027 }\end{array}$ & $\begin{array}{c}\text { E. coli } \\
\text { ATCC 7839 }\end{array}$ & C. albicans & A. flavus \\
\hline AgNPs & $15.0 \pm 0.20$ & $16.5 \pm 1.50$ & $21.5 \pm 1.3$ & $19.0 \pm 0.20$ & $12.5 \pm 0.45$ & $14.0 \pm 0.15$ \\
\hline
\end{tabular}

The maximal growth inhibition was observed in case of Gram-negative bacteria both for $P$. aerugi$n o s a$ and $E$. coli with $21.5 \pm 1.3$ and $19.0 \pm 0.20 \mathrm{~mm}$, respectively. While the minimum growth inhibition was recorded for Gram-positive bacteria B. subtilis and $S$. aureus with $15.0 \pm 0.20$ and $16.5 \pm 1.50 \mathrm{~mm}$, respectively. At the same time weak antifungal activity was observed for both $A$. flavus and $C$. albicans with $14.0 \pm 0.15$ and $12.5 \pm 0.45 \mathrm{~mm}$, respectively.

Biologically synthesized AgNPs showed good antimicrobial activity against Gram-positive, Gramnegative bacteria as well as against unicellular multicellular fungi. Nanomaterials are the leaders in the field of nanomedicine, bionanotechnology and have a great importance in nano toxicology research. Silver exhibits the strong toxicity in various chemical forms to a wide range of microorganism that is very well known and AgNPs have recently been shown to be a promising antimicrobial material [46]. Silver ions

Int. j. biol. chem. (Online) have been known to bind with the negatively charged cell wall resulting in the rupture and consequent denaturation of proteins which leads to cell death [52]. The synthesized AgNPs with smaller size can act drastically on cell membrane and further interact with DNA and causes damage [53]. Other proposed mechanisms include the AgNPs causing depletion of intracellular ATP by rupture of plasma membrane or by blocking respiration in association with oxygen and sulfhydryl $(-\mathrm{S}-\mathrm{H})$ groups on the cell wall to form R-S-S-R bonds thereby leading to cell death [54].

\section{Conclusion}

Silver nanoparticles synthesized by the green chemistry approach reported in this study using lemon peels extract can be used as an antimicrobial agent in biomedicine and pharmaceutics. This study demonstrated that synthesized AgNPs have spherical

International Journal of Biology and Chemistry 12, № 2, 56 (2019) 
shape within nanorange of $9.3 \mathrm{~nm}$ to $20.3 \mathrm{~nm}$ with the main diameter of $15.76 \mathrm{~nm}$ and have a promising antibacterial activity, with maximal growth inhibition against both $P$. aeruginosa and $E$. coli of 21.5 \pm 1.3 and $19.0 \pm 0.20 \mathrm{~mm}$, respectively, as well as antifungal activity against both $A$. flavus and C. albicans with mean diameter of inhibition zone of 14.0 \pm 0.15 and $12.5 \pm 0.45 \mathrm{~mm}$, respectively. Biogenic method used in this study is non-toxic, environmentally friendly, simple, and low-cost.

\section{Acknowledgement}

The research was conducted within the framework of the grant No. 7687-SAR-2018-3-9-F from Deanship of Scientific Research, Northern Border University, Arar, Saudi Arabia.

\section{References}

1. Kiran G., Dhasayan A., Lipton N., Selvin J., Arasu V., Al-Dhabi A. (2014) Melanin-templated rapid synthesis of silver nanostructures. $J$ Nanobiotechnol., vol. 12, no. 1, pp. 1-18.

2. Lee V., Hamid B., Zain K. (2014) Conversion of lignocellulosic biomass to nanocellulose: structure and chemical process. Sci World J., vol. 2014, no. 2, pp. 1-20.

3. Tian D., Hu J., Bao J., Chandra P., Saddler N., Lu C. (2017) Lignin valorization: lignin nanoparticles as high-value bio-additive for multifunctional nanocomposites. Biotechnol Biofuels, vol. 10, no. 192, pp.1-11.

4. Singh K., Panghal M., Kadyan, S., Chaudhary U., Yadav P. (2014) Green silver nanoparticles of Phyllanthus amarus: as an antibacterial agent against multi drug resistant clinical isolates of $\mathrm{Pseu}$ domonas aeruginosa. J Nanobiotechnol., vol. 2014, no. 12 , pp. 40.

5. Ahmed S., Ahmad M., Swami L., Ikram S. (2016) A review on plants extract mediated synthesis of silver nanoparticles for antimicrobial applications: a green expertise. $J$ Adv Res., vol. 7, no. 1, pp.17-28.

6. Duman F., Ocsoy I., Kup F. (2016) Chamomile flower extract-directed $\mathrm{CuO}$ nanoparticle formation for its antioxidant and DNA cleavage properties. Mater Sci Eng C., vol. 60, no. 1, pp. 333-338.

7. Jewett C., Patolsky P. (2013) Nanobiotechnology: synthetic biology meets materials science. Curr Opin Biotechnol., vol. 24, no. 4, pp. 551-554.

8. Bhyan B., Alam M., Ali S. (2007) Effect of plant extracts on Okra mosaic virus incidence and Int. j. biol. chem. (Online) yield related parameters of Okra.J Agric Res., vol. 1, no. 1, pp. 112-118.

9. Calvo A., Angulo E., Costa-Batllori P., Shiva C., Adelantado C., Vicente A. (2006) Natural plant extracts and organic acids: synergism and implication on piglet's intestinal microbiota. Biotechnol., vol. 5, no. 2, pp. 137-142.

10. Cao L., Cheng C., Ma L., Zhao S. (2010) Preparation of silver nanoparticles with antimicrobial activities and the researches of their biocompatibilities. J Mater Sci Mater M., vol. 21, no. 10, pp. 2861-2868.

11. Chandan S., Vineet S., Pradeep N., Vikas K., Harvinder S. (2011) A green biogenic approach for synthesis of gold and silver nanoparticles using Zingiber officinale. Digest J Nanomat Biostruc., vol. 6, no. 2, pp. 535-542.

12. Dastjerdi R., Montazer M., Shahsavan S. (2010) Size-controlled preparation of silver nanoparticles by a modified polyol method, Colloids Surf. $A$ Physicochem Eng Aspects, vol. 366, no. 1, pp. 197202.

13. Du L., Niu S., Xu L., Xu R., Fan L. (2009) Antibacterial activity of chitosan tripolyphosphate nanoparticles loaded with various metal ions. Carbohydr Polym., vol. 75, no. 3, pp. 385-389.

14. Huang J., Li Q., Sun D., Lu Y., Su Y., Yang X., Wang H., Wang Y., Shao W., He N., Hong J., Chen C. (2007) Biosynthesis of silver and gold nanoparticles by novel sundried Cinnamomum camphora leaf. Nanotech., vol. 18, no. 10, pp. 105-109.

15. Barros E., Madalossi N., Sigoli A., Mazali O. (2015) Silver nanoparticles: green synthesis, selfassembled nanostructures and their application as SERS substrates. New J Chem., vol. 39, no. 4, pp. 2839-2846.

16. Awad M., Hendi A., Ortashi K., et al. (2014) Silver nanoparticles biogenic synthesized using an orange peel extract and their use as an anti-bacterial agent. Int J Phys Sci., vol. 9, no. 3, pp. 34-40.

17. Vankar P., Shukla D. (2012) Biosynthesis of silver nanoparticles using lemon leaves extract and its application for antimicrobial finish on fabric. Appl Nanosci., vol. 2, no. 2, pp. 163-168.

18. Augustine R., Kalarikkal N., Thomas S. (2014) A facile and rapid method for the black pepper leaf mediated green synthesis of silver nanoparticles and the antimicrobial study. Appl. Nanosci., vol. 4, no. 1, pp. 809-818.

19. Demirbas A., Welt B., Ocsoy I. (2016) Biosynthesis of red cabbage extract directed Ag NPs and their effect on the loss of antioxidant activity. Mater Lett., vol. 179, no. 3, pp. 20-23. 
20. Ocsoy I., Demirbas A., McLamore E., Altinsoy B., Ildize N., Baldemir A. (2017) Green synthesis with incorporated hydrothermal approaches for silver nanoparticles formation and enhanced antimicrobial activity against bacterial and fungal pathogens. $J \mathrm{Mol}$ Liq., vol. 238, no. 1, pp. 263-269.

21. Medda S., Hajra A., Dey U., Bose P., Mondal K. (2015) Biosynthesis of silver nanoparticles from Aloe vera leaf extract and antifungal activity against Rhizopus sp. and Aspergillus sp. Appl Nanosci., vol. 5, no. 1 , pp. 875-880.

22. Amooaghaie R., Saeri M., Azizi M. (2015) Synthesis, characterization and biocompatibility of silver nanoparticles synthesized from Nigella sativa leaf extract in comparison with chemical silver nanoparticles. Ecotoxicol Environ Saf., vol. 120, no. 2, pp. 400-408.

23. Khan M., Khan M., Adil S., et al. (2013) Green synthesis of silver nanoparticles mediated by Pulicaria glutinosa extract. Int J Nanomed., vol. 8, no. 3, pp. 1507-1516.

24. Emmanuel R., Palanisamy S., Chen S., et al. (2015) Antimicrobial efficacy of green synthesized drug blended silver nanoparticles against dental caries and periodontal disease causing microorganisms. Mater Sci Eng C., vol. 56, no. 4, pp. 374-379.

25. Prakash P., Gnanaprakasam P., Emmanuel R., Arokiyaraj S., Saravanan M. (2013) Green synthesis of silver nanoparticles from leaf extract of Mimusops elengi, Linn. for enhanced antibacterial activity against multi drug resistant clinical isolates. Colloids Surf B., vol. 108, no. 1, pp. 255-259.

26. Dhand V., Soumya L., Bharadwaj S., Chakra S., Bhatt D., Sreedhar B. (2016) Green synthesis of silver nanoparticles using Coffea arabica seed extract and its antibacterial activity. Mat Sci Eng C., vol. 58 , no. 1 , pp. 36-43.

27. Karatoprak G., Aydin G., Altinsoy B., Altinkaynak C., Koşar M., Ocsoy I. (2017) The Effect of Pelargonium endlicherianum Fenzl. root extracts on formation of nanoparticles and their antimicrobial activities. Enzyme Microb Technol., vol. 97, no. 1, pp. 21-26.

28. Akhtar M., Panwar J., Yun Y. (2013) Biogenic synthesis of metallic nanoparticles by plant extracts. ACS Sustainable Chem Eng., vol. 1, no. 6, pp. 591-602.

29. Jeong H., Yeo Y., Yi C. (2005) The effect of filler particle size on the antibacterial properties of compounded polymer/silver fibers. J Mat Sci., vol. 40, no. 20, pp. 5407-5411.

30. Kamyar S., Mansor A., Seyed J., Parvaneh S., Parvanh S., Hossein J., Yadollah S. (2012) Inves-

Int. j. biol. chem. (Online) tigation of antibacterial properties silver nanoparticles prepared via green method. Chem Centr J., vol. 6, no. 1 , pp. 73.

31. Khandelwal N., Singh A., Jain D., Upadhyay K., Verma N. (2010) Green synthesis of silver nanoparticles using Argimone mexicana leaf extract and evaluation of their antimicrobial activities. $J$ Nanomat Biostruct., vol. 5, no. 2, pp. 483-489.

32. Krutyakov A., Kudrynskiy A., Olenin Y., Lisichkin V. (2008) Extracellur biosynthesis and antimicrobial activity of silver nanoparticles. Russ Chem Rev., vol. 77, no. 1, pp. 233-236.

33. Marambio-Jones C., Hoek V. (2010) A review of the antibacterial effects of silver nanomaterials and potential implications for human health and the environment. J Nanopart Res., vol. 12, no. 5, pp. 1531-1551.

34. Muhammad A., Farooq A., Muhammad J., Muhammad I., Umer R. (2012) Green synthesis of silver nanoparticles through reduction with Solanum xanthocarpum $L$. berry extract: characterization, antimicrobial and urease inhibitory activities against Helicobacter pylori. Int J Mol Sci, vol. 13, no. 8, pp. 9923-9941.

35. Chung Y., Chung Y., Ngeow F., Goh H., Imiyabir Z. (2004) Antimicrobial activities of Malaysian plant species. Pharm Biol., vol. 42, no. 1, pp. 292-300.

36. Jain D., Daima K., Kachhwaha S., Kothari L. (2009) Synthesis of plant-mediated silver nanoparticles using papaya fruit extract and evaluation of their antimicrobial activities. Digest J Nanomat Biostruc., vol. 4, no. 4, pp. 723-727.

37. Palanivel V., Sang-Myung L., Mahudunan L., Kui-Jae L., Byung-Taek O. (2013) Pine cone-mediated green synthesis of silver nanoparticles and their antibacterial activity against agricultural pathogens. Appl Microbiol Biotechnol., vol. 97, no. 1, pp. 361-368.

38. Savage N., Diallo S. (2005) Nanomaterials and water purification. opportunities and challenges. Nanopart. Res., vol. 7, no. 4, pp. 331-342.

39. Savithramma N., Linga M., Rukmini K., Suvarnalatha D. (2011) Antimicrobial activity of silver nanoparticles synthesized by using medicinal plants. Int J Chem Technol Res., vol. 3, no. 3, pp. 1394-1402.

40. Saxena A., Tripathi M., Singh P. (2010) Biological synthesis of silver nanoparticles by using Onion (Allium cepa) extract and their antibacterial activity. J Nanomater Biostruct., vol. 5, no. 2, pp. 427-432.

41. Setua P., Chakraborty A., Seth D., Bhatta U., Satyam V., Sarkar N. (2007) Synthesis, optical 
properties, and surface enhanced Raman scattering of silver nanoparticles in nonaqueous methanol reverse micelles. $N J$ Phys Chem C., vol. 111, no. 10, pp. 3901-3907.

42. Sharma K., Yngard A., Lin Y. (2009) Silver nanoparticles: Green synthesis and their antimicrobial activities. Adv Coll Int Sci., vol. 145, no. 1-2, pp. 83-96.

43. Shankar, S.S.; A. Rai, et al. (2004) Rapid synthesis of Au, Ag, and bimetallic Au core- Ag shell nanoparticles using Neem (Azadirachta indica) leaf broth. J Coll Interface Sci., vol. 275, no. 2, pp. 496502.

44. Ankamwar B., Chaudhary M., et al. (2005) Gold nanotriangles biologically synthesized using tamarind leaf extract and potential application in vapor sensing. Synth React Inorg Metal-Org., Nano-Metal Chem., vol. 35, no. 1, pp. 19-26.

45. Chandran P., Chaudhary M., et al. (2006) Synthesis of gold nanotriangles and silver nanoparticles using Aloe vera plant extract. Biotech Progress, vol. 22 , no. 2 , pp. $577-583$.

46. Ip M., Lui L., Poon M., Lung I., Burd A. (2006) Antimicrobial activities of silver dressings: an in vitro comparison. J. Medical Microb., vol. 55, no. 3, pp. 59-63.

47. Bar H., Bhui H., Sahoo G., Sarkar P., De P., Misra A. (2009) Green synthesis of silver nanoparticles using latex of Jatrapha curcas. Colloids Surf. A Physicochem Eng Asp., vol. 339, no. 1-3, pp. 134139.
48. Magudapathy P., Gangopadhyay P., Panigrahi K., Nair M., Dhara S. (2001) Electrical transport studies of Ag nanoclusters embedded in glass matrix. Physica B., vol. 299, no. 1-2, pp. 142-146.

49. El-Batal I., Haroun M., Farrag A., Baraka A., El-Sayyad S. (2014) Synthesis of silver nanoparticles and incorporation with certain antibiotic using gamma irradiation. Brit J Pharm Res., vol. 4, no. 11, pp. 1341-1363.

50. Awad A., Hendi A., Khalid O., Ortashi F., Elradi A., Eisa E., Al-lahieb L., Al-Otiby M., Merghani M., Awad A. (2014) Silver nanoparticles biogenic synthesized using an orange peel extract and their use as an anti-bacterial agent. Int $J$ Phys Sci., vol. 9, no. 3, pp. 34-40.

51. Padma S., Dhara S. (2012) Biosynthesis of silver nanoparticles by lemon leaves extract and its application for antimicrobial finish on fabric. Appl Nanosci., vol. 2, no. 2, pp.163-168.

52. Senapati S., Ahmad A., Khan I., Sastry M., Kumar R. (2005) Extracellular biosynthesis of bimetallic Au-Ag alloy nanoparticles. Small., vol. 1, no. 5, pp. 517-520.

53. Pridham G., Anderson P., Foley C., Lindenfelser L., Hesselting W., Benedict C. (1956) A selection of media for maintenance and taxonomic study of Streptomyces. Antibiotics Ann., vol. 3, no. 1, pp. 947-953.

54. Lechevalier A., Williams T., Sharpe E., Holt G. (1989) The Actinomycetes: a practical guide to genetic identification of actinomycetes. In: Berge's Manual of Systematic Bacteriology, pp. 2344-3330. 